Prepared in cooperation with the Maine Department of Environmental Protection

\title{
June and August Median Streamflows Estimated for Ungaged Streams in Southern Maine
}

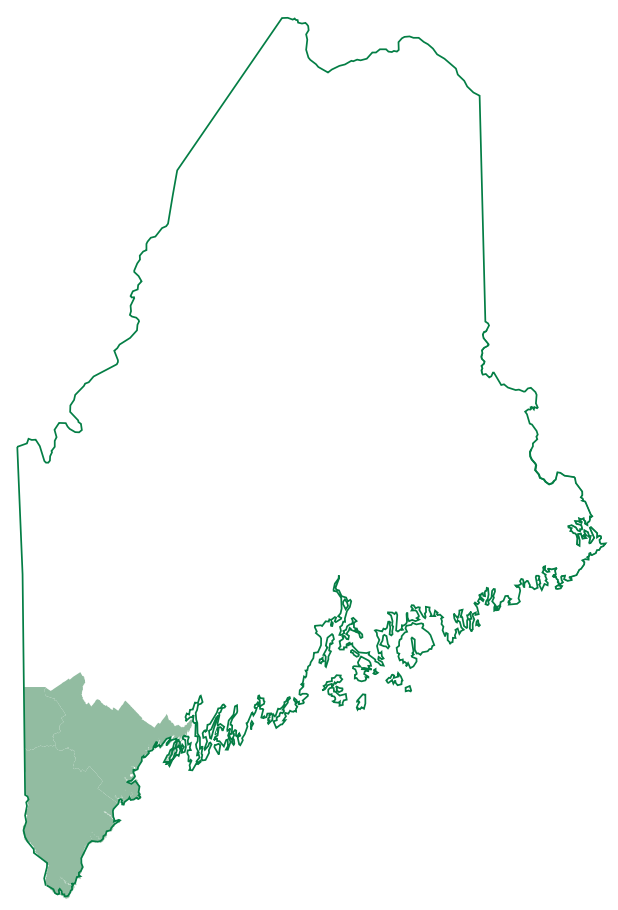

Scientific Investigations Report 2010-5179 
Cover. Map shows location of study area. 


\section{June and August Median Streamflows Estimated for Ungaged Streams in Southern Maine}

By Pamela J. Lombard

Prepared in cooperation with the Maine Department of Environmental Protection

Scientific Investigations Report 2010-5179 


\title{
U.S. Department of the Interior \\ KEN SALAZAR, Secretary \\ U.S. Geological Survey \\ Marcia K. McNutt, Director
}

\section{U.S. Geological Survey, Reston, Virginia: 2010}

\author{
For more information on the USGS — the Federal source for science about the Earth, its natural and living resources, \\ natural hazards, and the environment, visit http://www.usgs.gov or call 1-888-ASK-USGS \\ For an overview of USGS information products, including maps, imagery, and publications, \\ visit http://www.usgs.gov/pubprod \\ To order this and other USGS information products, visit http://store.usgs.gov
}

Any use of trade, product, or firm names is for descriptive purposes only and does not imply endorsement by the U.S. Government.

Although this report is in the public domain, permission must be secured from the individual copyright owners to reproduce any copyrighted materials contained within this report.

Suggested citation:

Lombard, P.J., 2010, June and August median streamflows estimated for ungaged streams in southern Maine: U.S. Geological Survey Scientific Investigations Report 2010-5179, 16 p., at http://pubs.usgs.gov/sir/2010/5179/. 


\section{Contents}

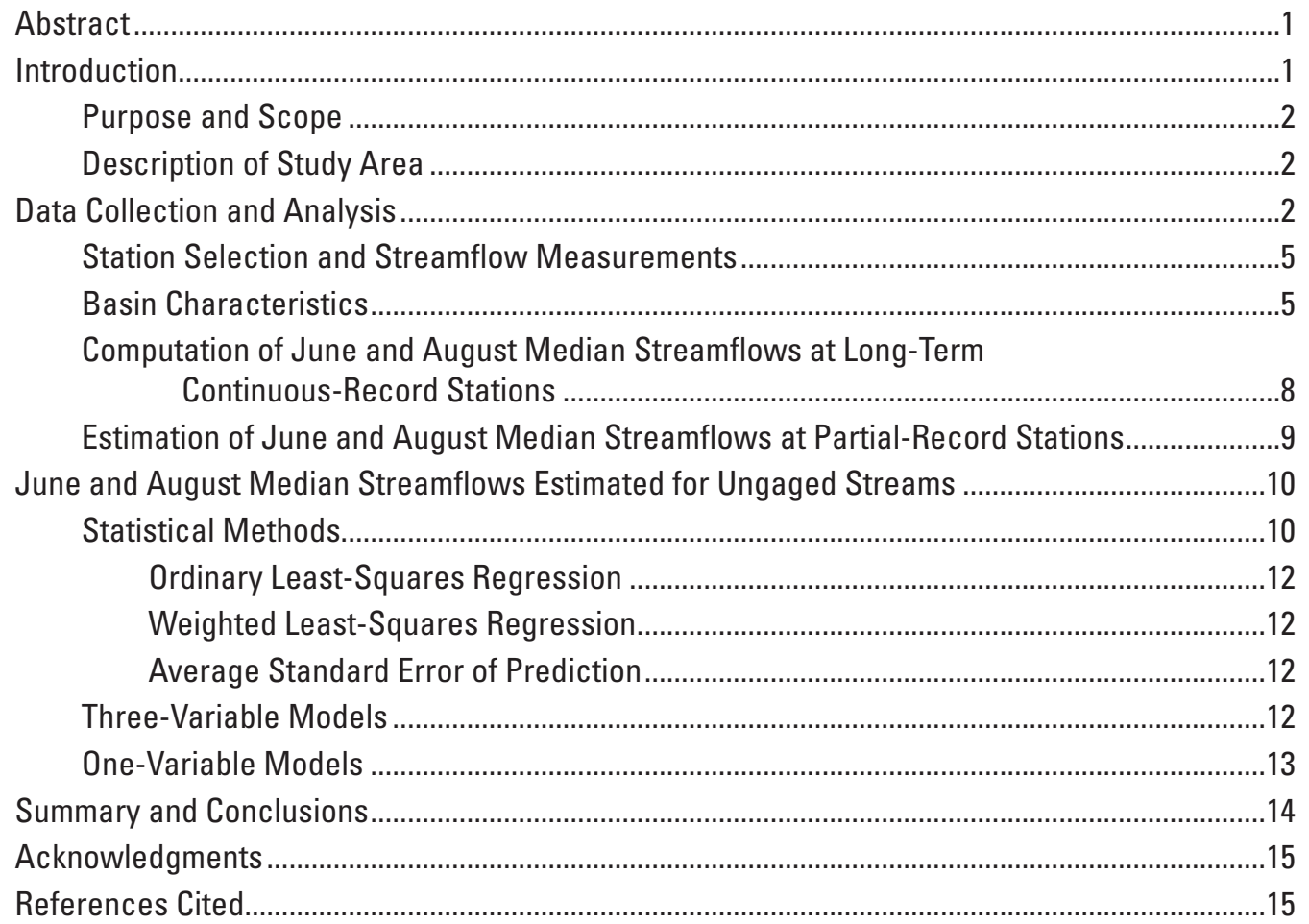

\section{Figures}

1. Map showing location of study area, Gulf of Maine line, and streamgage stations used as index stations in Maine, New Hampshire, and Massachusetts.

2. Map showing location of partial-record and continuous-record streamgage stations used in regression analyses for southern Maine.....

3. Graph showing relation of base-flow measurements at partial-record station Wescott Brook near Gorham, Maine, USGS station number 010641125, and concurrent daily mean streamflow at index station Little Androscoggin River near South Paris, Maine, USGS station number 01057000, 2006-08...

4. Graph showing two-dimensional range of explanatory variables drainage area and percentage of basin underlain by sand and gravel aquifers used in regression equations for predicting June and August median streamflows on ungaged streams in southern Maine.

5. Graph showing two-dimensional range of explanatory variables drainage area and distance from the basin centroid to the Gulf of Maine line used in regression equations for predicting June and August median streamflows on ungaged streams in southern Maine. 


\section{Tables}

1. Partial-record streamgage stations and selected basin characteristics used in regression analyses, southern Maine.

2. Long-term continuous-record streamgage stations and selected basin characteristics used in regression analyses, southern Maine.

3. Long-term continuous-record streamgage stations in Maine, New Hampshire, and Massachusetts used as index stations.

4. Point coordinates that define the Gulf of Maine line.

5. Weighted June and August median streamflows at partial-record streamgage stations in southern Maine

\section{Conversion Factors and Datum}

Inch/Pound to SI

\begin{tabular}{lll}
\hline \multicolumn{1}{c}{ Multiply } & By & \multicolumn{1}{c}{ To obtain } \\
\hline inch (in.) & Length & \\
foot $(\mathrm{ft})$ & 2.54 & centimeter $(\mathrm{cm})$ \\
mile (mi) & 0.3048 & meter $(\mathrm{m})$ \\
\hline & 1.609 & kilometer $(\mathrm{km})$ \\
\hline square foot $\left(\mathrm{ft}^{2}\right)$ & Area & \\
square foot $\left(\mathrm{ft}^{2}\right)$ & 929.0 & square centimeter $\left(\mathrm{cm}^{2}\right)$ \\
square mile $\left(\mathrm{mi}^{2}\right)$ & 0.09290 & square meter $\left(\mathrm{m}^{2}\right)$ \\
\hline & 2.590 & square kilometer $\left(\mathrm{km}^{2}\right)$ \\
\hline cubic foot per second $\left(\mathrm{ft}^{3} / \mathrm{s}\right)$ & Flow rate & \\
cubic foot per second per square mile & 0.02832 & cubic meter per second $\left(\mathrm{m}^{3} / \mathrm{s}\right)$ \\
{$\left[\left(\mathrm{ft}^{3} / \mathrm{s}\right) / \mathrm{mi}^{2}\right]$} & 0.01093 & cubic meter per second per square \\
& & kilometer $\left[\left(\mathrm{m}^{3} / \mathrm{s}\right) / \mathrm{km}^{2}\right]$ \\
\hline
\end{tabular}

Vertical coordinate information is referenced to the North American Vertical Datum of 1988 (NAVD 88).

Horizontal coordinate information is referenced to the North American Datum of 1983 (NAD 83). 


\title{
June and August Median Streamflows Estimated for Ungaged Streams in Southern Maine
}

\author{
By Pamela J. Lombard
}

\section{Abstract}

Methods for estimating June and August median streamflows were developed for ungaged, unregulated streams in southern Maine. The methods were developed using streams with drainage areas ranging in size from 0.4 to 74 square miles, with percentage of basin underlain by a sand and gravel aquifer ranging from 0 to 84 percent, and with distance from the centroid of the basin to a Gulf of Maine line paralleling the coast ranging from 14 to 94 miles. Equations were developed with data from 4 long-term continuous-record streamgage stations and 27 partial-record streamgage stations. Estimates of median streamflows at the continuous-record and partial-record stations are presented. A mathematical technique for estimating standard low-flow statistics, such as June and August median streamflows, at partial-record streamgage stations was applied by relating base-flow measurements at these stations to concurrent daily streamflows at nearby long-term (at least 10 years of record) continuous-record streamgage stations (index stations). Weighted least-squares regression analysis (WLS) was used to relate estimates of June and August median streamflows at streamgage stations to basin characteristics at these same stations to develop equations that can be used to estimate June and August median streamflows on ungaged streams. WLS accounts for different periods of record at the gaging stations.

Three basin characteristics - drainage area, percentage of basin underlain by a sand and gravel aquifer, and distance from the centroid of the basin to a Gulf of Maine line paralleling the coast - are used in the final regression equation to estimate June and August median streamflows for ungaged streams. The three-variable equation to estimate June median streamflow has an average standard error of prediction from -35 to 54 percent. The three-variable equation to estimate August median streamflow has an average standard error of prediction from -45 to 83 percent. Simpler one-variable equations that use only drainage area to estimate June and August median streamflows were developed for use when less accuracy is acceptable. These equations have average standard errors of prediction from -46 to 87 percent and from -57 to 133 percent, respectively.

\section{Introduction}

The State of Maine recently adopted In-stream Flow Standards (Maine State Legislature, 2007) to maintain streamflows according to the natural variations of flows and water levels. Maine's In-stream Flow Standards are based on six seasonal base flows - winter, spring, early summer, summer, fall, and early winter - and are intended to be protective of natural aquatic life and designated water uses. Early summer and summer seasonal flows have been defined in the In-stream Flow Standards to be equivalent to June and August median flows, respectively. Currently (2010) few streamgage stations on small streams in southern Maine (drainage areas less than $100 \mathrm{mi}^{2}$ ) have sufficient long-term records (at least 10 years) to estimate low-flow statistics in this region. For sites without a streamgage station, equations used to estimate streamflow statistics on the basis of basin characteristics are critical tools for estimating low-flow statistics and for monitoring and maintaining Maine's flow standards. Streamflow statistics, such as monthly median streamflows, are used to evaluate water availability and the adequacy of streamflow at a site for the development of water supplies, disposal of wastes, generation of electricity, irrigation of agricultural land, maintenance and restoration of aquatic habitat, and conservation of watersheds. Equations are not yet available to estimate monthly median flows for ungaged basins of all sizes throughout the state of Maine.

In most cases a central value of a distribution of streamflows, such as the median, is preferable to a value that may be skewed by a few extreme observations, such as the mean (Helsel and Hirsch, 1992). The median streamflows referred to in this report are based on the mean of the monthly medians of the annual series of flows for June and August, respectively. Not only does this computational method provide an estimate of expected flows in June or August, but it also allows for an estimation of the error of this estimate. Methods for estimating low-flow statistics at partial-record stations on the basis of correlations between daily mean discharges at the partial-record streamgage stations and concurrent daily mean discharges at nearby continuous-record streamgage stations are presented by Riggs (1972). Riggs also outlines a technique 
of regionalizing low-flow characteristics of rivers by multiple regression of basin characteristics, such as drainage area and surficial geology.

Equations are currently available to estimate monthly median flows throughout the State for basins ranging in size from 10 to $1,400 \mathrm{mi}^{2}$ (Dudley, 2004). Statewide equations use basin characteristics such as drainage area, percentage of basin underlain by a sand and gravel aquifer, and distance to a Gulf of Maine line that parallels the coast to estimate the annual 7-day low flow with a 10-year recurrence interval (7Q10) and monthly mean and median flows in Maine.

The equations in this report add to the set of Maine regression equations used to estimate streamflows of all magnitudes at all locations and basin sizes within the state. This is the third in a series of reports developing regional equations for estimating August median flows on small basins in Maine. The southern Maine equations presented here complement equations previously developed for northern and eastern Maine. The regional studies of small basins on ungaged streams in eastern Aroostook County, Maine, (Lombard and others, 2003) and August median streamflows on ungaged streams in eastern coastal Maine (Lombard, 2004b) have demonstrated that estimates of August median streamflow developed from statewide equations designed for basins with large drainage areas (greater than $10 \mathrm{mi}^{2}$ ) and small percentages of sand and gravel aquifers (less than 30 percent) are not applicable to all small basins (less than $10 \mathrm{mi}^{2}$ ) in Maine, especially those basins underlain by greater than 30 percent sand and gravel aquifers. The percentage of the basin underlain by sand and gravel aquifers and the drainage area were used in the equation to estimate August median streamflows for small basins in eastern coastal Maine (Lombard, 2004b). Mean basin elevation and drainage area were used in the equation to estimate August median streamflows for small basins in eastern Aroostook County, Maine (Lombard and others, 2003). A fact sheet developed to provide guidance for selecting and applying Maine streamflow regression equations can be accessed at http://pubs.usgs.gov/fs/2004/3001/ (Lombard, 2004a).

Management and effective use of water resources in southern Maine could benefit from low-flow estimation techniques developed specifically for small streams in this region. Thus in 2006, the U.S. Geological Survey (USGS) began a 5-year cooperative study with the Maine Department of Environmental Protection (MDEP) to develop regression equations that could be used to improve estimates of June and August median streamflows for ungaged, unregulated streams in southern Maine.

\section{Purpose and Scope}

This report presents equations to be used for the estimation of June and August median streamflows for streams in York, Cumberland, and southwestern Oxford Counties in southern Maine, as well as an estimate of the accuracy of these equations. The report describes (1) how instantaneous streamflow measurements at 27 partial-record streamgage stations were correlated to daily mean streamflows at long-term continuous-record streamgage stations to estimate June and August median streamflows at the partial-record stations and (2) how regression equations were developed to predict June and August median streamflows on small, ungaged streams by using data from 4 long-term continuous-record and 27 partialrecord streamgage stations.

\section{Description of Study Area}

This study includes sites in York, Cumberland, and southern Oxford Counties in southern Maine (fig. 1). York and Cumberland counties encompass 991 and $835 \mathrm{mi}^{2}$, respectively, and as of 2007, had populations of 201,000 and 275,000 , respectively (U.S. Census Bureau, 2009). This is the most heavily populated region of Maine. The surficial geologic materials of the basins in these counties are predominantly crystalline and sedimentary rocks overlain by glacial deposits. Localized, discontinuous sand and gravel aquifers are scattered throughout the region (Thompson and Borns, 1985).

The major river basins in southern Maine are the Piscataqua River Basin, which drains 1,018 $\mathrm{mi}^{2}$ and includes the Salmon Falls River Basin (these rivers form Maine's southern border with New Hampshire); the Saco River Basin, which drains 1,700 $\mathrm{mi}^{2}$ at the mouth; and the Presumpscot River Basin, which drains $647 \mathrm{mi}^{2}$ at the mouth and includes Sebago Lake. In addition, there are many small coastal river basins that drain directly to the Atlantic Ocean, including the Royal River, the Mousam River, the Kennebunk River, and the York River Basins (fig. 2).

Cold winters and cool summers typify the climate in southern Maine. The average annual temperature based on the 30 -year period from 1971 to 2000 in Portland is $45.7^{\circ} \mathrm{F}$; mean monthly temperatures ranged from $21.7^{\circ} \mathrm{F}$ in January to $68.7^{\circ} \mathrm{F}$ in July. The mean annual precipitation is $45.8 \mathrm{in}$. in Portland. Precipitation is uniformly distributed throughout the year (National Oceanic and Atmospheric Administration, 2002). High streamflows typically occur in spring and late fall, and low streamflows generally occur in the summer and early fall. During the summer months, streamflow comes from groundwater discharged from aquifers (base flow) and rainfall from summer storms.

\section{Data Collection and Analysis}

A continuous-record streamgage station (continuousrecord station) is a station that records data with sufficient frequency to define daily mean streamflows. A partial-record streamgage station (partial-record station) is a station at which discrete measurements are made over a period of time without continuous data being recorded or computed. For the purposes of this report, continuous-record stations are divided into those with less than 10 years of record (short-term stations) 


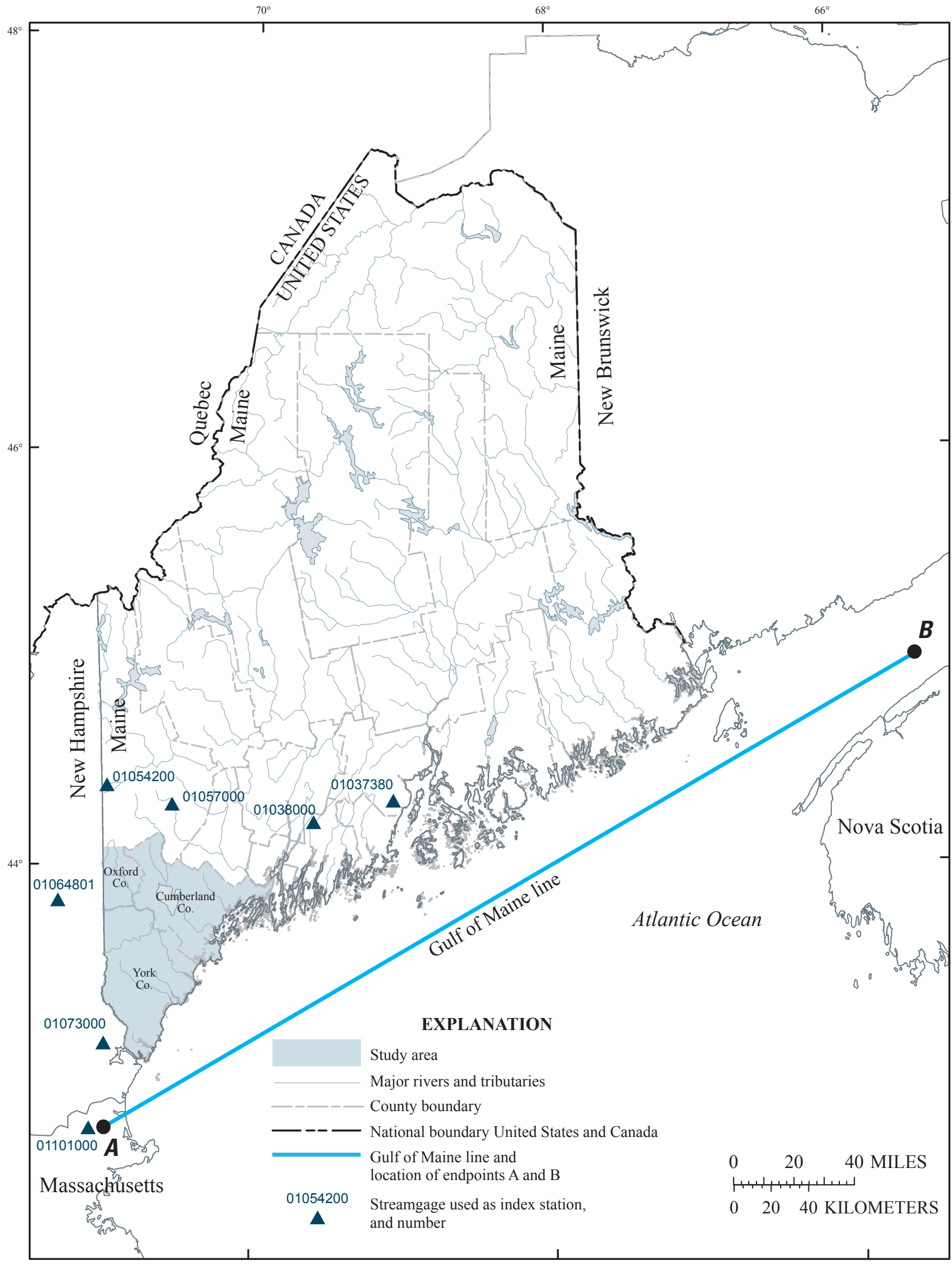

Base from U.S. Geological Survey digital files, scale 1:2,000,000 projection Universal Transverse Mercator, zone 19

Figure 1. Location of study area, Gulf of Maine line, and streamgage stations used as index stations in Maine, New Hampshire, and Massachusetts. 


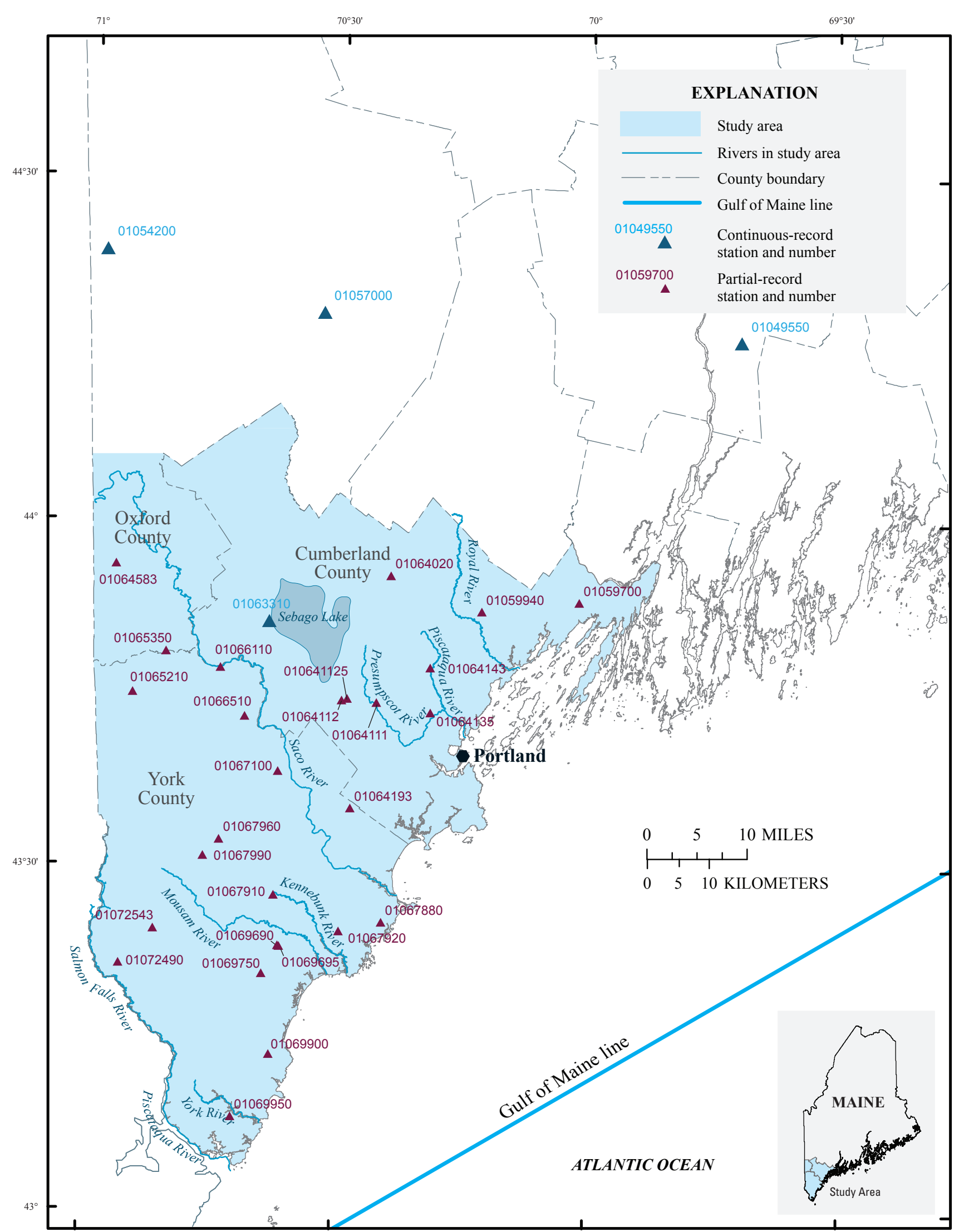

Base from U.S. Geological Survey digital files, scale 1:2,000,000 Streams and brooks are not shown on this scale of map. projection Universal Transverse Mercator, zone 19

Figure 2. Location of partial-record and continuous-record streamgage stations used in regression analyses for southern Maine. 
and those with equal to or greater than 10 years of record (long-term stations). Although 10 years of record is defined as long-term for this report due to the very few streamgage stations in this region, it is the minimum to be used in calculating streamflow statistics, such as monthly median streamflow because longer periods result in more accurate statistics. Index stations have long-term mean daily streamflow measurements that correlate well with base-flow measurements made at a partial-record station.

Ideally, equations used to estimate June and August median streamflows on small, ungaged streams in southern Maine would be developed with long-term data from stations on small streams in the same region. Because there was only one continuous-record station on a small unregulated stream in southern Maine at the beginning of this study (2006), streamflow data for partial-record stations extended by using streamflow measurements from index stations located in central Maine, southeastern New Hampshire, and northeastern Massachusetts were used to develop the equations (fig. 1). Low-flow statistics at long-term stations were calculated directly from the data.

\section{Station Selection and Streamflow Measurements}

Twenty-seven partial-record stations were established for this project (table 1). In addition, four long-term continuousrecord stations in Maine with drainage areas of less than $75 \mathrm{mi}^{2}$ and located within $30 \mathrm{mi}$ of the study area were used in the regression analyses (table 2). Of the four long-term stations used (fig. 2), one is no longer in operation (Togus Stream at Togus, Maine, 01049550) but has sufficient historical record to calculate monthly median flows. Thus 31 stations were used in the regression analyses to develop equations to estimate June and August median streamflows on ungaged streams. All 31 stations have relatively small drainage areas (from 0.4 to $75 \mathrm{mi}^{2}$ ) and are within $30 \mathrm{mi}$ of the study area (fig. 2). All 31 stations are unregulated, meaning that they are unaltered by human activities such as impoundments, diversions, and (or) withdrawals.

Continuous-record stations were chosen as index stations if their daily mean flow correlated with base-flow measurements made at a partial-record station and were used to estimate streamflow statistics at the partial-record stations. Ten long-term continuous-record stations were tested for use as index stations, including the three long-term stations described above that are currently in operation and seven additional stations - all with drainage areas of 0.73 to $145 \mathrm{mi}^{2}$. Stations were required to have a period of record concurrent with the record of a partial-record station in order to be used as an index station. Ideally, index stations would be close to partial-record stations geographically and have drainage areas about the same size as the drainage areas of the partial-record stations (less than $100 \mathrm{mi}^{2}$ ). Because few long-term continuous-record stations in the region meet these criteria, stations located up to $50 \mathrm{mi}$ away from the region, including two stations in New Hampshire and one station in Massachusetts, were tested for use as index stations. Seven long-term stations were chosen as index stations on the basis of streamflow correlations with at least one partial-record station (fig. 1; table 3). The range of the periods of record for the selected index stations is 10 to 94 years. All streamflow data for continuous-record and partial-record stations can be found online (U.S. Geological Survey, 2010).

Standard USGS methods were used to make all streamflow measurements at the partial-record stations. Measurements were made using wading current-meter methods, portable Parshall flume methods, and volumetric methods (Rantz and others, 1982). Streamflows at the partialrecord stations were measured during independent base flows, flows separated by periods of direct runoff associated with rainstorms. A range of flows throughout the summer months was needed, and flows that changed rapidly or flows that could be attributed directly to direct runoff were avoided. Measurements of independent low-flow events were made within a 30-hour period at all stations.

\section{Basin Characteristics}

Basin characteristics evaluated for use as explanatory variables had to make hydrologic sense, be reasonably easy to measure, and have the potential to explain a significant amount of the variability of the response variable. Topographic, climatic, and geologic basin characteristics that could potentially explain some of the variability of June or August median streamflows were delineated and calculated using a geographic information system (GIS). All coordinates and distance measurements were referenced to the North American Datum of 1983 (NAD 83), Universal Transverse Mercator zone 19 coordinate system.

In all, eight categories of basin characteristics were evaluated. (1) Drainage area, the area of each drainage basin in square miles, was delineated manually in GIS using the best available topographic data (typically 10 to 20-foot contour lines from USGS 1:24,000 quadrangles). The intersection of these drainage-basin boundaries with other GIS layers were used for calculating additional basin characteristics. (2) Minimum, maximum, and mean basin elevation; elevation range; and mean basin slope were calculated from the intersection of the drainage area boundary with USGS 10-meter digital elevation models (DEMs). The DEM was converted into a slope layer using the Spatial Analyst extension, and the mean basin slope (as a percent) was calculated for each basin. (3) The percentage of the basin underlain by sand and gravel aquifers was calculated from the intersection of the drainage area boundary with sand and gravel aquifer map polygons made by the Maine Department of Conservation, Maine Geological Survey, at a 1:24,000 scale accessed under aquifer polygons at http://megis.maine.gov/ catalog/ (Maine Geological Survey, 2003). (4) Percentage 
Table 1. Partial-record streamgage stations and selected basin characteristics used in regression analyses, southern Maine.

[USGS, U.S. Geological Survey; Latitude and longitude are referenced to the North American Datum of 1983; ${ }^{\prime}$ " , degrees, minutes and seconds; mi ${ }^{2}$, square miles; trib, tributary; All partial-record stations had at least 10 base-flow measurements between 2006 and 2008]

\begin{tabular}{|c|c|c|c|c|c|c|c|}
\hline $\begin{array}{c}\text { USGS } \\
\text { station } \\
\text { number }\end{array}$ & Station name and location & $\begin{array}{l}\text { Latitude } \\
\left(0^{\circ}, "\right)\end{array}$ & $\begin{array}{c}\text { Longitude } \\
\left(0^{\circ}, "\right)\end{array}$ & $\begin{array}{l}\text { Index } \\
\text { station } \\
\text { number }\end{array}$ & $\begin{array}{c}\text { Drain- } \\
\text { age } \\
\text { area } \\
\left(\mathrm{mi}^{2}\right)\end{array}$ & $\begin{array}{c}\text { Percentage } \\
\text { of basin } \\
\text { underlain } \\
\text { by sand } \\
\text { and gravel } \\
\text { aquifer }\end{array}$ & $\begin{array}{l}\text { Distance } \\
\text { from basin } \\
\text { centroid } \\
\text { to Gulf of } \\
\text { Maine line } \\
\text { (miles) }\end{array}$ \\
\hline 01059700 & Bunganuc Stream near Brunswick, Maine & 435314.55 & 700110.20 & 01037380 & 3.82 & 1.26 & 42.5 \\
\hline 01064111 & Black Brook near South Windham, Maine & 434431.41 & 702519.00 & 01057000 & 3.67 & 0.00 & 44.9 \\
\hline 01064112 & North Branch Little River near Gorham, Maine & 434431.24 & 702934.05 & 01101000 & 4.46 & 16.3 & 46.0 \\
\hline 01064135 & Meader Brook near Falmouth, Maine & 434332.57 & 701854.19 & 01057000 & 1.14 & 0.19 & 40.6 \\
\hline 01064143 & Piscataqua River near Cumberland Center, Maine & 434727.13 & 701859.27 & 01037380 & 14.5 & 9.09 & 45.0 \\
\hline 01065210 & Great Brook near Parsonfield, Maine & 434458.02 & 705436.84 & 01054200 & 2.56 & 5.14 & 55.8 \\
\hline 01065350 & Wadsworth Brook near Cornish, Maine & 434833.81 & 705044.39 & 01057000 & 3.54 & 3.51 & 59.6 \\
\hline 01066110 & Back Brook near Cornish, Maine & 434715.34 & 704406.92 & 01101000 & 4.84 & 22.4 & 52.9 \\
\hline 01066510 & Black Brook near Limington, Maine & 434302.62 & 704109.57 & 01064801 & 6.46 & 5.99 & 49.2 \\
\hline 01067100 & Junkins Brook near Hollis Center, Maine & 433816.91 & 703703.48 & 01054200 & 2.56 & 49.1 & 43.4 \\
\hline 01067880 & Little River near Goose Rocks Beach, Maine & 432516.27 & 702426.69 & 01073000 & 5.40 & 6.13 & 25.3 \\
\hline 01067910 & Carlisle Brook near Days Mill, Maine & 432731.27 & 703720.26 & 01064801 & 8.75 & 12.8 & 32.2 \\
\hline 01067920 & Goff Mill Brook near Kennebunk, Maine & 432426.67 & 702929.73 & 01073000 & 4.88 & 0.00 & 26.8 \\
\hline 01069950 & Dolly Gordon Brook near York Village, Maine & 430811.57 & 704157.87 & 01064801 & 1.42 & 0.00 & 14.3 \\
\hline 01072490 & Great Brook near West Lebanon, Maine & 432124.43 & 705540.17 & 01057000 & 9.22 & 0.36 & 36.1 \\
\hline 01072543 & Bog Brook near Lebanon, Maine & 432427.88 & 705138.9 & 01101000 & 9.21 & 0.00 & 37.8 \\
\hline 010641125 & Westcott Brook near Gorham, Maine & 434440.61 & 702852.79 & 01057000 & 3.02 & 24.3 & 46.4 \\
\hline
\end{tabular}



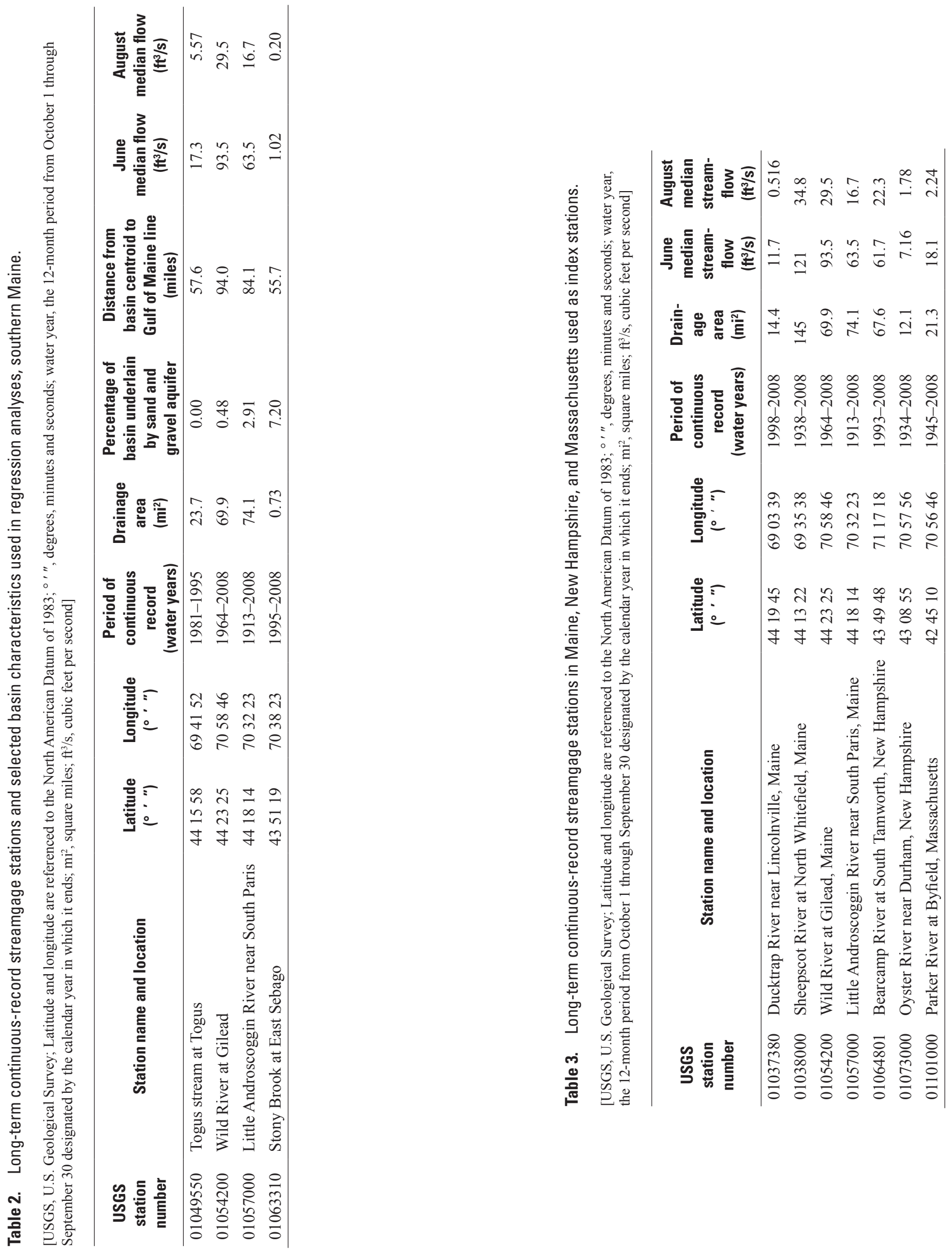
ponds, the areal percentage of lakes, ponds, and reservoirs in a basin, was calculated from National Hydrography Dataset (NHD) waterbodies data layer (U.S. Geological Survey, 2008).

(5) Percentage wetlands, the areal percentage of all types of wetlands in a basin, and (6) percentage total storage, the areal percentage of all types of wetlands, lakes, ponds, reservoirs and rivers in a basin, were calculated from the intersection of drainage basin polygons with digital National Wetland Inventory maps produced by U.S. Fish and Wildlife Service at a scale of 1:24,000 (U.S. Fish and Wildlife Service, 2008) in combination with the NHD waterbodies layer.

The locations of the basin centroids were determined in GIS and were used in calculating additional basin characteristics. (7) Mean monthly and annual precipitation at the basin centroids for each basin were computed using Parameter-elevation Regressions on Independent Slopes Model (PRISM) output grids (Daly and Neilson, 1992; Daly and others, 1997) (accessed at http://www.wcc.nrcs.usda.gov/ climate/prism.html on March 2009) and converted to inches.

(8) Distance from the centroid of the basin to a Gulf of Maine line was calculated as the shortest distance (in miles) from the centroid of the basin to an arbitrary Gulf of Maine line paralleling the coast (fig. 1). The end coordinates (points A and B, fig. 1) of the Gulf of Maine line are given in table 4. The shortest distance between a basin centroid and the Gulf of Maine line is a perpendicular intersector of the Gulf of Maine line. The Gulf of Maine line is an indicator of distance from the Atlantic Ocean which can affect moisture available during storms (Dudley, 2010). The base-10 logarithmic transformation of many of the basin characteristics also was calculated and tested for use in the equations.

\section{Computation of June and August Median Streamflows at Long-Term Continuous-Record Stations}

June and August median streamflows for nine longterm continuous-record stations in southern Maine, New Hampshire, and Massachusetts were calculated from June and August annual monthly median streamflow series at each station (tables 2 and 3). Calculated medians were used for the regression equations, for the stations used as an index station, or both (USGS stations 01054200 and 01057000 are listed in both tables 2 and 3). Although the Mann Kendall trend test (Helsel and Hirsch, 1992) indicated that there was no evidence of trends over time in the annual series of June or August medians for any of the long-term stations at a $p$-value equal to 0.05 or less, several of the stations did not have sufficient periods of record to make such a trend test meaningful. The projected monthly median streamflows for June and August were estimated by computing the mean of the observed annual June and August medians, respectively. This method of computing the monthly median streamflows closely approximates the method of using the daily mean streamflow that is exceeded 50 percent of the time during any
Table 4. Point coordinates that define the Gulf of Maine line.

[Latitude and longitude coordinates are referenced to North American Datum of 1983, meter coordinates are referenced to Universal Transverse Mercator Zone 19 datum, Gulf of Maine line is shown in figure 1]

\begin{tabular}{lll}
\hline & \multicolumn{1}{c}{ X-coordinate } & \multicolumn{1}{c}{ Y-coordinate } \\
\hline \multirow{3}{*}{ Point A } & $71^{\circ} 0^{\prime} 0^{\prime \prime}$ west longitude & $42^{\circ} 45^{\prime} 0^{\prime \prime}$ north latitude \\
& 336321.28 meters & 4734992.89 meters \\
& $65^{\circ} 30^{\prime} 0^{\prime \prime}$ west longitude & $45^{\circ} 0^{\prime} 0^{\prime \prime}$ north latitude \\
Point B & 775853.75 meters & 4988911.83 meters \\
\hline
\end{tabular}

given month throughout the period of record but is preferable because it allows for the calculation of the variance around the median. The estimate of variance is essential for the weighted least-squares regression analyses and provides an estimate of error for the final regression equations.

\section{Estimation of June and August Median Streamflows at Partial-Record Stations}

In order to estimate June and August medians for partialrecord stations and determine standard deviations of these medians, the logarithm of the measured streamflows needs to have a linear correlation with the logarithm of the concurrent daily mean streamflows at an index station. An example of the correlation between concurrent measurements for a partial-record station and an index station is shown in figure 3. A partial-record station was required to have a correlation coefficient of 0.70 or greater with an index station in order to be used in this analysis. If measurements at a partialrecord station correlated well (coefficient greater than 0.70 ) with measurements from more than one index station, then the index station with the higher correlation coefficient was used. If the correlation coefficient was similar for two index stations, then the index station used was chosen on the basis of a visual observation of the graphical relation between the two stations.

June and August median streamflows for the partialrecord stations were estimated by use of a least-squaresregression analysis of the logarithms of the flows after confirmation that the base-flow measurements at the partial-record station had an adequate linear relation with the concurrent daily streamflows at an index station. Stedinger and Thomas (1985) developed a technique to estimate the mean and standard deviation of an annual event such as the d-day T-year low flow, which is the annual, minimum d-day consecutive low flow that will be exceeded, on average, every $\mathrm{T}$ years. Using this technique to calculate the monthly median at a partialrecord station, as opposed to the d-day T-year low flow, is appropriate if the logarithms of the monthly medians at the index station are approximately normally distributed. For all 


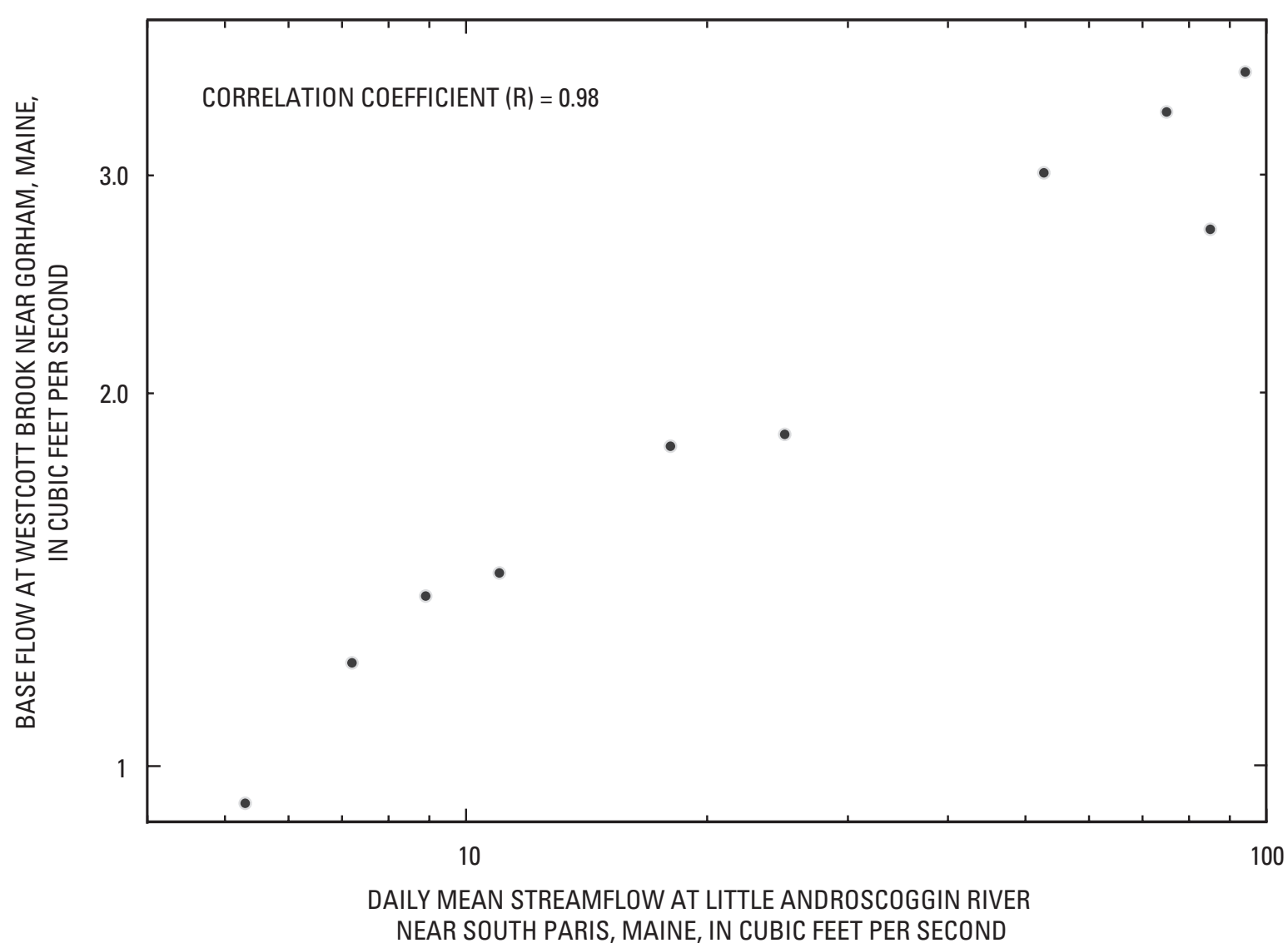

Figure 3. Relation of base-flow measurements at partial-record station Wescott Brook near Gorham, Maine, USGS station number 010641125, and concurrent daily mean streamflow at index station Little Androscoggin River near South Paris, Maine, USGS station number 01057000, 2006-08.

index stations used in this study, except Sheepscot River at North Whitefield, Maine (USGS station number 01038000), the logarithms of the monthly medians were normally distributed during both June and August. Although the logarithms of the August medians were not normally distributed at Sheepscot River, the logarithms of the median of the annual series of August medians was equal to the logarithms of the mean of the annual series of August means at this station, and thus the Stedinger and Thomas (1985) technique was still considered valid. The Stedinger and Thomas (1985) technique was used to calculate the June and August median streamflows and the error of the estimates at all partial-record stations (table 5).

Base-flow measurements at the partial-record station, the corresponding daily mean streamflows at an index station, total number of years of record at the index station, and the median and standard deviation of the base-10 logarithms of the June and August median streamflows at the index station were used to compute the base-10 logarithms of the median streamflow and its variance at the partial-record station. Estimates of median flows for 27 partial-record stations are presented in table 5 .

Five partial-record stations (USGS stations 01064111, 01067960, 01069900, 01069950, and 01072543) had one measurement of zero streamflow each. Ordinary least-squares regression is based on the assumption that the residuals from the regression equation are approximately normally distributed. A logarithmic transformation of streamflow is generally required to achieve approximate normality; however, the occurrence of zero flows makes the logarithmic transformation difficult to apply. Thus the median streamflows and standard errors for these five sites were computed using only the non-zero observations after determining graphically from the correlation with an index site that the estimates of June and August median flows at these sites were greater than zero. 
Table 5. Weighted June and August median streamflows at partial-record streamgage stations in southern Maine.

[USGS, U.S. Geological Survey; $\mathrm{ft}^{3} / \mathrm{s}$, cubic feet per second; $\mathrm{ft}^{3} / \mathrm{s} / \mathrm{mi}^{2}$, cubic feet per second per square mile; trib, tributary]

\begin{tabular}{|c|c|c|c|c|c|}
\hline $\begin{array}{c}\text { USGS } \\
\text { station } \\
\text { number }\end{array}$ & Partial-record station name and location & $\begin{array}{c}\text { Weighted } \\
\text { June median } \\
\text { streamflow } \\
\left(\mathrm{ft}^{3} / \mathbf{s}\right)\end{array}$ & $\begin{array}{c}\text { Weighted } \\
\text { August median } \\
\text { streamflow } \\
\left(\mathrm{ft}^{3} / \mathrm{s}\right)\end{array}$ & $\begin{array}{l}\text { Weighted } \\
\text { June median } \\
\text { streamflow } \\
\left(\mathrm{ft}^{3} / \mathrm{s} / \mathrm{mi}^{2}\right)\end{array}$ & $\begin{array}{c}\text { Weighted } \\
\text { August median } \\
\text { streamflow } \\
\left(\mathrm{ft}^{3} / \mathrm{s} / \mathrm{mi}^{2}\right)\end{array}$ \\
\hline 01059700 & Bunganuc Stream near Brunswick & 1.32 & 0.22 & 0.35 & 0.06 \\
\hline 01059940 & Kenny Brook near Crockett Corner & 17.7 & 8.22 & 0.64 & 0.30 \\
\hline 01064020 & Sucker Brook near Gray & 1.80 & 0.78 & 0.61 & 0.27 \\
\hline 01064111 & Black Brook near South Windham & 1.84 & 0.35 & 0.50 & 0.09 \\
\hline 01064112 & North Branch Little River near Gorham & 4.66 & 2.88 & 1.04 & 0.65 \\
\hline 01064135 & Meader Brook near Falmouth & 0.73 & 0.23 & 0.64 & 0.20 \\
\hline 01064143 & Piscataqua River near Cumberland Center & 15.2 & 3.57 & 1.05 & 0.25 \\
\hline 01064193 & Skilley Brook near Scarborough & 0.29 & 0.21 & 0.69 & 0.50 \\
\hline 01064583 & Shepards River near Brownfield & 25.9 & 11.6 & 1.45 & 0.65 \\
\hline 01065210 & Great Brook near Parsonfield & 1.75 & 0.80 & 0.68 & 0.31 \\
\hline 01065350 & Wadsworth Brook near Cornish & 2.64 & 0.80 & 0.75 & 0.23 \\
\hline 01066110 & Back Brook near Cornish & 5.85 & 3.44 & 1.21 & 0.71 \\
\hline 01066510 & Black Brook near Limington & 4.24 & 0.49 & 0.66 & 0.08 \\
\hline 01067100 & Junkins Brook near Hollis Center & 3.40 & 2.46 & 1.32 & 0.96 \\
\hline 01067880 & Little River near Goose Rocks Beach & 1.65 & 0.58 & 0.31 & 0.11 \\
\hline 01067910 & Carlisle Brook near Days Mill & 6.43 & 1.91 & 0.74 & 0.22 \\
\hline 01067920 & Goff Mill Brook near Kennebunk & 1.07 & 0.23 & 0.22 & 0.05 \\
\hline 01067960 & Carl Branch Brook near Waterboro & 1.68 & 0.28 & 0.98 & 0.16 \\
\hline 01067990 & Middle Branch Mousam River near Sanford & 5.99 & 0.91 & 0.94 & 0.14 \\
\hline 01069690 & Branch Brook near Wells & 19.1 & 11.5 & 2.50 & 1.50 \\
\hline 01069695 & Unnamed trib to Branch Brook near Wells & 0.80 & 0.23 & 1.10 & 0.32 \\
\hline 01069750 & Merriland River near Wells & 5.90 & 2.59 & 0.65 & 0.29 \\
\hline 01069900 & Clay Hill Brook near Mount Agamenticus & 0.27 & 0.03 & 0.15 & 0.02 \\
\hline 01069950 & Dolly Gordon Brook near York Village & 0.49 & 0.12 & 0.34 & 0.08 \\
\hline 01072490 & Great Brook near West Lebanon & 5.24 & 0.62 & 0.57 & 0.07 \\
\hline 01072543 & Bog Brook near Lebanon & 6.37 & 0.74 & 0.69 & 0.08 \\
\hline 010641125 & Westcott Brook near Gorham & 2.93 & 1.67 & 0.97 & 0.55 \\
\hline
\end{tabular}




\section{June and August Median Streamflows Estimated for Ungaged Streams}

Multiple linear regression analyses were used to develop equations to estimate June and August median streamflows on ungaged streams. June and August median streamflows at the 31 partial- and continuous-record stations were related statistically to physical and climatic characteristics of the drainage basins of these stations. The explanatory variables drainage area, percentage of basin underlain by a sand and gravel aquifer, and distance from the drainage basin centroid to the Gulf of Maine line best explain the variability in the response variables June and August median streamflows and are included in the final regression equations. If these basin characteristics can be calculated, equations can be used to estimate June or August median streamflow on a river in the absence of streamflow data.

\section{Statistical Methods}

Initially, variations in the June and August median streamflows were related to variations in the drainage-basin characteristics through ordinary least-squares regression analysis (OLS) (Helsel and Hirsch, 1992). Regressions of all possible subsets in OLS were used to reduce the number of drainage-basin characteristics and determine the best combination of explanatory variables for use in the final equation. Weighted least-squares (WLS) regression techniques were used to develop the final equations and estimates of accuracy presented in this report. Stedinger and Tasker (1985) showed that WLS regression techniques are more appropriate than OLS for regionalizing streamflow statistics where the streamflow records at the index stations are of varying lengths.

A modified version of the Weighted Multiple Linear Regression Program (WREG), WREGvMedian, was used for the regression analysis described in this report (Eng and others, 2009). This program is identical to the standard WREG program except that weighting matrices are constructed to be appropriate for median flows. The WLS option in WREGvMedian weights each station included in the regression on the basis of the variance of the estimated median streamflow. Estimates with large variance are more uncertain, and hence, those stations are given smaller weight. For continuous-record stations, the variance is calculated based on Equation 2 in Lombard and others (2003, p. 14). For partialrecord stations, the variance is based on the equation provided in Stedinger and Thomas (1985). Regression coefficients are estimated using an iterative search procedure (Stedinger and Tasker, 1985; Eng and others, 2009). A generalized least-squares (GLS) option that roughly follows the methods described in Lombard and others (2003) also was tested in order to account for the cross-correlation of concurrent streamflows due to the fact that in some cases multiple partial-record stations were correlated with the same index station. The GLS results were comparable to the WLS results; therefore, the extra complexity associated with application of the GLS method was deemed unnecessary for this study.

\section{Ordinary Least-Squares Regression}

OLS equations were developed in a regression of all possible subsets. To establish linearity, logarithmic transformations of the response variables (June and August median streamflows) and one of the explanatory variables (drainage area) were performed. The equations with the strongest relations between the explanatory variables and the response variables were chosen on the basis of the $p$-values of the T-statistic, the adjusted $\mathrm{R}^{2}$, and Mallow's Cp statistic (Helsel and Hirsch, 1992). The $p$-values of the T-statistic indicate the significance of the individual explanatory variables. The adjusted $R^{2}$ value indicates the amount of variance in the response variable explained by the explanatory variable(s), and Mallow's Cp statistic is a compromise between maximizing the explained variance by including all relevant variables and minimizing the standard error by keeping the number of variables as small as possible (Helsel and Hirsch, 1992). Typically the $p$-values of the T-statistic have been found to be significant at $p=<0.05$, and the Cp statistic is less than or equal to the number of explanatory variables plus one in order to indicate a meaningful equation; however, there are no absolute cutoff points for these statistics, and results need to be evaluated within the context of the project. Partial residual plots and residuals in relation to predicted plots were examined. The best models were tested for regression assumptions including linearity, homoscedasticity (constant variance in the response variable over the range of explanatory variables), and normality. The best models for both June and August median stramflows that satisfied the above mentioned criteria had the following explanatory variables: the logarithm of the drainage area, the percentage of basin underlain by a sand and gravel aquifer, and the distance from the basin centroid to the Gulf of Maine line.

\section{Weighted Least-Squares Regression}

The final models, their coefficients, and their estimates of error were selected using WLS regression because WLS can adjust for streamflow records of different lengths. Models that used the explanatory variables drainage area, percentage of basin underlain by a sand and gravel aquifer, and the distance from the basin centroid to the Gulf of Maine line minimized the standard error and maximized the explained variance for the June and August median streamflows, respectively. Additional models using only drainage area were selected for both June and August monthly median streamflows for cases where use of a simplified model with reduced accuracy was considered acceptable. Residuals determined by applying the final models were mapped for each partial-record station, and no spatial patterns were found using the models for either month. 


\section{Average Standard Error of Prediction}

The average standard error of prediction (ASEP) is a measure of the uncertainty of a prediction obtained using the regression equation - or a measure of how well the regression equation estimates the response variable when it is applied to ungaged drainage basins that were not used to develop the equation. For OLS regression, the ASEP is calculated as the mean square error (MSE) (a measure of the variability of observations about the regression line) plus the sampling error variance of the model coefficients (a measure of the uncertainty in the placement of the regression line). WLS regression, however, allows for the partition of the MSE into the model error variance (the portion of the MSE that results from an imperfect model, and which is relevant to the ASEP) and the sampling error variance of the residuals (the portion of the MSE that can be attributed to imprecise estimates of the observed dependent variable due to finite record length, and which is not relevant for ASEP). Thus for WLS, the ASEP is calculated as the sum of the model error variance plus the sampling error variance of the model coefficients. There is a 68-percent probability that the true value of median streamflow at a station will be within the range of the ASEP.

\section{Three-Variable Models}

The final equations using drainage area (DRNAREA) in square miles, percentage of basin underlain by sand and gravel aquifers (PCTSNDGRV), and the distance from the basin centroid to the Gulf of Maine line (GOMDIST) in miles to predict June (JUND50) and August (AUGD50) median streamflows on ungaged streams are

$$
\begin{aligned}
& J U N D 50=0.2151(\text { DRNAREA })^{0.9812} 10^{0.0086(P C T S N D G R V)} 10^{0.0096(G O M D I S T)} \\
& A U G D 50=0.0310(D R N A R E A)^{0.9057} 10^{0.0172(\text { PCTSNDGRV })} 10^{0.0155(\text { GOMDIST }),}
\end{aligned}
$$

where
JUND50
is June median streamflow in cubic feet per second,
AUGD50 is August median streamflow in cubic feet per second,
DRNAREA is drainage area in square miles,
PCTSNDGRV is percentage of basin underlain by sand and gravel aquifers, and
GOMDIST is the distance from the basin centroid to the Gulf of Maine line in miles.

For June median streamflow, drainage area, percentage of basin underlain by a sand and gravel aquifer, and distance to the Gulf of Maine line are all significant ( $p$-values less than 0.0001 , equal to 0.0001 , and equal to 0.0006 , respectively). The ASEP is from -35 to 54 percent. For August median streamflow, drainage area, fraction of basin underlain by a sand and gravel aquifer, and distance to the Gulf of Maine line are all significant ( $p$-values all less than or equal to 0.0001), and the ASEP is from -45 to 83 percent.
The equations listed above are appropriate for predicting June and August median streamflows at unregulated drainage basins on ungaged streams in York, Cumberland, and southern Oxford Counties within the two-dimensional ranges of variables shown by the shaded area in figures 4 and 5 . If the equations are used with explanatory variables outside the twodimensional ranges shown in these figures, or if the explanatory variables are calculated with methods other than those outlined in this report, then the resulting estimates of June and August median streamflows will be of unknown accuracy. 


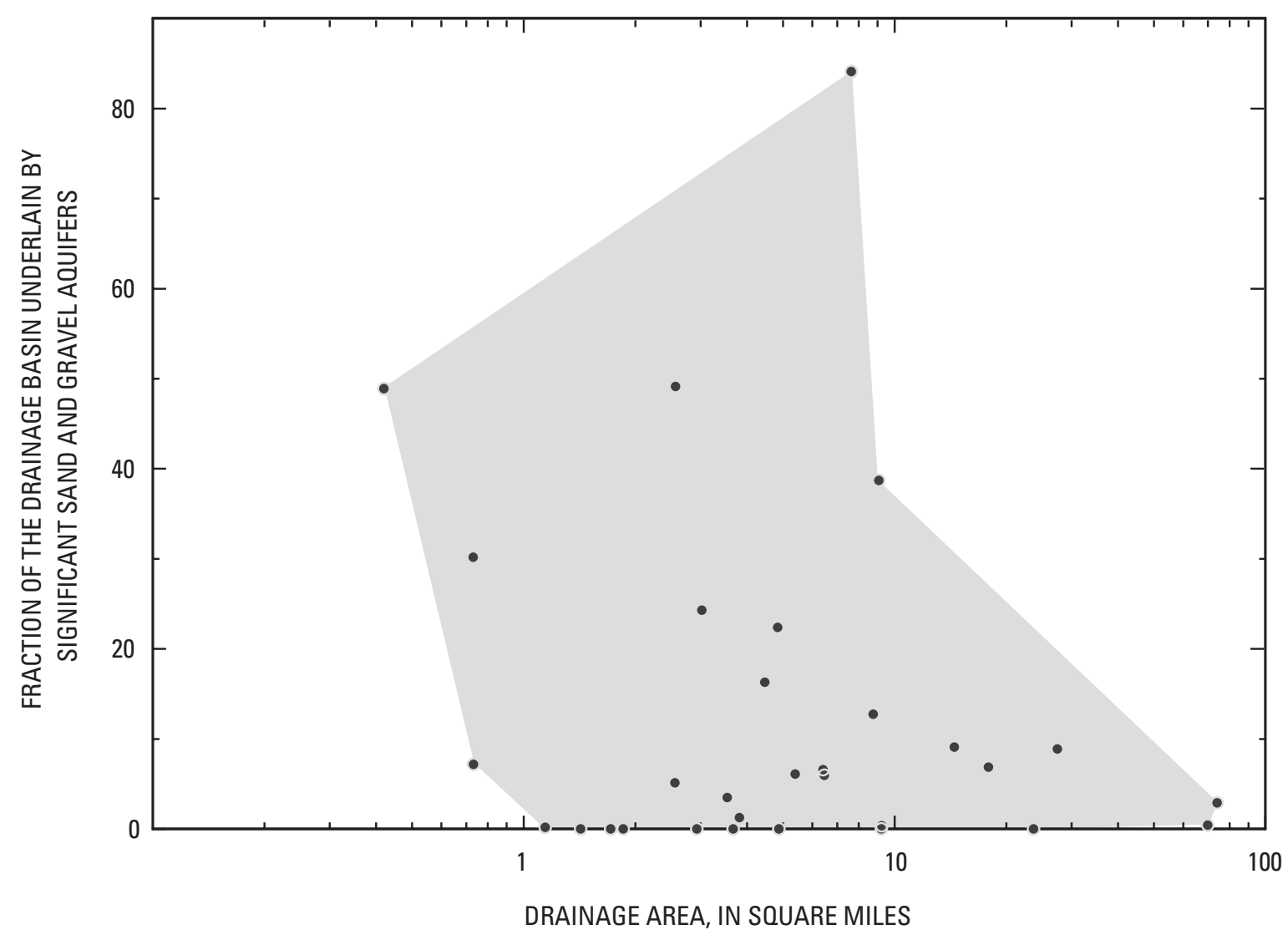

Figure 4. Two-dimensional range (shaded area) of explanatory variables drainage area and percentage of basin underlain by sand and gravel aquifers used in regression equations for predicting June and August median streamflows on ungaged streams in southern Maine.

\section{One-Variable Models}

Simplified equations using only drainage area (DRNAREA) in square miles to estimate June and August median streamflows on ungaged streams (JUND50 and $A U G D 50$, respectively) are presented below. These equations are faster and easier to apply than the three-variable model but are to be used only when estimates of less accuracy are acceptable.
For June median streamflow, drainage area is highly significant $(p$-value $<0.0001)$. The average standard error of prediction is from -46 to 87 percent. For August median streamflow, drainage area is also highly significant ( $p$-value $<0.0001)$. The average standard error of prediction is from -57 to 133 percent.

$$
\begin{gathered}
J U N D 50=0.6566(D R N A R E A)^{1.081} \\
A U G D 50=0.1973(D R N A R E A)^{1.0597}
\end{gathered}
$$




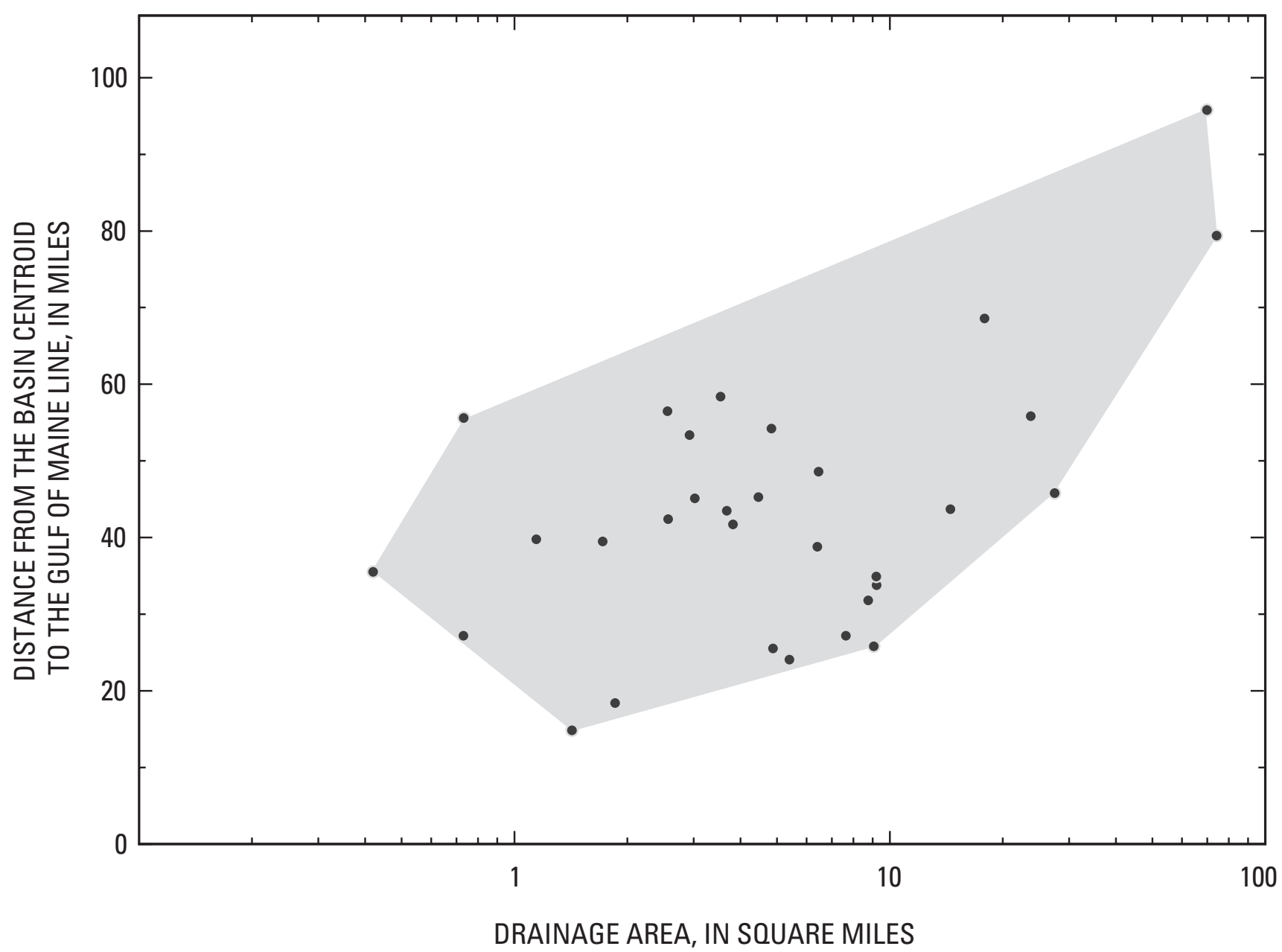

Figure 5. Two-dimensional range (shaded area) of explanatory variables drainage area and distance from the basin centroid to the Gulf of Maine line used in regression equations for predicting June and August median streamflows on ungaged streams in southern Maine.

\section{Summary and Conclusions}

In 2006, the U.S. Geological Survey began a cooperative study with the Maine Department of Environmental Protection to evaluate June and August median streamflow at existing continuous-record stations in southern Maine, develop new partial-record stations at some of the locations where continuous-record stations were not available, estimate June and August median streamflows at new partial-record stations, and develop equations to estimate June and August median streamflows on small ungaged streams in southern Maine.
Equations with known estimates of accuracy are a critical part of Maine's In-stream Flow Standards adopted in 2007; however, equations that are currently (2010) available for estimating low-flow statistics statewide in Maine were not designed for basins of less than 10 square miles. Currently there are few streamgage stations in southern Maine with sufficient periods of record for the calculation of long-term June and August medians.

In order to develop equations to estimate June and August median streamflows for small basins in southern Maine, 27 new partial-record stations were established to augment data from 4 long-term stations. Instantaneous streamflow 
measurements at partial-record stations were correlated to daily mean streamflow at long-term continuous-record streamgage stations in southern Maine, New Hampshire, and Massachusetts in order to estimate June and August median streamflows at the partial-record stations included in this report. Estimates of June and August median streamflows at both partial-record and continuous-record stations were analyzed with basin characteristics determined using basin boundaries in order to develop regression equations to estimate selected low-flow statistics for small, ungaged streams.

Drainage area, the percentage of the basin underlain by sand and gravel aquifers, and the distance from the basin centroid to the Gulf of Maine line are the basin characteristics that were best able to predict the June and August median streamflows on stream basins in York, Cumberland, and southwestern Oxford Counties in southern Maine. The equations were developed using weighted least-squares regression - in which each station included in the regression is weighted on the basis of the variance of its estimated median streamflow. Estimates with large variance are more uncertain, and hence, those stations are given smaller weight. Equations presented in this report can only be used for ungaged stream locations with basin characteristics within the range of values used in the development of the equations. Application of the equations to streams that do not meet these criteria will provide results with unknown accuracy.

Estimates made using the equations are more meaningful if they are accompanied by estimates of the error of the results. The equation to estimate June median streamflow has an average standard error of prediction (ASEP) from -35 to 54 percent. The equation to estimate August median streamflow has an ASEP from -45 to 83 percent. Simpler onevariable equations that use only drainage area to estimate June and August median streamflows were developed for use when less accuracy is acceptable. These equations have ASEPs from -46 to 87 percent and from -57 to 133 percent, respectively. There is a greater difference in errors between the one-variable equation and the 3 -variable equation to estimate August mean streamflow than between the one-variable equation and the 3-variable equation to estimate June median streamflow. The equations to estimate June and August median streamflows with one-variable are designed to be used only in situations where the additional basin characteristics cannot be determined.

\section{Acknowledgments}

The author thanks Julie Kiang and Ken Eng of the USGS for providing substantial assistance in the statistical analyses in this report. In addition, the author thanks the following USGS personnel for assisting in the collection of field data for this report: Nick Stasulis, Martha Nielsen, Jim Caldwell and Josh Kempf.

\section{References Cited}

Daly, C., and Neilson, R.P., 1992, A digital topographic approach to modeling the distribution of precipitation in mountainous terrain, in Jones, M.E., and Laenen, A., eds., Interdisciplinary approaches in hydrology and hydrogeology: American Institute of Hydrology, p. 437-454.

Daly, C., Taylor, G.H., and Gibson, W.P., 1997, The PRISM approach to mapping precipitation and temperature: Proceedings of the 10th AMS Conference on Applied Climatology, American Meteorological Society, Reno Nevada, October 20-23, 1997, p. 10-12.

Dudley, R.W., 2004, Estimating monthly, annual, and low 7-day, 10-year streamflows for ungaged rivers in Maine: U.S. Geological Survey Scientific Investigations Report 2004-5026, 22 p.

Eng, Ken, Chen, Yin-Yu, and Kiang, J.E., 2009, User's guide to the weighted-multiple-linear-regression program (WREG version 1.0): U.S. Geological Survey Techniques and Methods, book 4, chap. A8, 21 p. (Available at http://pubs.usgs.gov/tm/tm4a8).

Helsel, D.R., and Hirsch, R.M., 1992, Statistical methods in water resources: New York, Elsevier, 522 p.

Lombard, P.J., 2004a, Methods for estimating streamflow statistics for ungaged streams in Maine: U.S. Geological Survey Fact Sheet FS-2004-3001, 2 p.

Lombard, P.J., 2004b, August median streamflow on ungaged streams in eastern coastal Maine: U.S. Geological Survey Scientific Investigations Report 2004-5157, 15 p.

Lombard, P.J., Tasker, G.D., and Nielsen, M.G., 2003, August median streamflow on ungaged streams in eastern Aroostook County, Maine: U.S. Geological Survey WaterResources Investigations Report 03-4225, 20 p.

Maine Geological Survey, 2003, Sand and gravel aquifer mapping, served by the Maine office of GIS, accessed September 2, 2003, at http://megis.maine.gov/catalog.

Maine State Legislature, 2007, In-stream flows and lake and pond water levels, 2007, Sec 1. 38 MRSA c.3, sub-c.I, article 4-B.

National Oceanic and Atmospheric Administration, 2002, Monthly station normals of temperature, precipitation, and heating and cooling degree days 1971-2000: Climatography of the United States, no. 81.

Rantz, S.E., and others, 1982, Measurements and computation of streamflow volume 1, measurement of stage and discharge: U.S. Geological Survey Water-Supply Paper 2175, $284 \mathrm{p}$. 
Riggs, H.C., 1972, Low-flow investigations: U.S. Geological Survey Techniques of Water-Resources Investigations, book 4, chap. B1, $18 \mathrm{p}$.

Stedinger, J.R., and Tasker, G.D., 1985, Regional hydrologic analysis 1 , Ordinary, weighted, and generalized leastsquares compared: Water Resources Research, v. 21, no. 9, p. 1421-1432.

Stedinger, J.R., and Thomas, W.O., 1985, Low-flow frequency estimation using base-flow measurements: U.S. Geological Survey Open-File Report 85-95, 22 p.

Thompson, W.B., and Borns, H.W., Jr., 1985, Surficial geologic map of Maine: Maine Geological Survey, scale 1:500,000.

U.S. Census Bureau, 2009, State and county quick facts, served by the U.S. Census Bureau, accessed March 31, 2009, at http://quickfacts.census.gov/qfd/ states/23/23005.html.

U.S. Fish and Wildlife Service, 2008, National Wetlands Inventory Maps, vector digital data from Maine Office of Geographic Information Systems, scale 1:24,000, accessed March 2008, at http://megis.maine.gov/catalog/.

U.S. Geological Survey, 2008, National Hydrography Dataset, accessed March 2008, at http://nhd.usgs.gov/index.html.

U.S. Geological Survey, 2010, National Water Information System, accessed January 13, 2010, at http://waterdata.usgs.gov/me/nwis/sw. 
Prepared by the Pembroke Publishing Service Center.

For more information concerning this report, contact:

Director

U.S. Geological Survey

Maine Water Science Center

196 Whitten Road

Augusta, ME 04330

dc_me@usgs.gov

or visit our Web site at:

http://me.water.usgs.gov 
